\title{
Genome size versus geographic range size in birds
}

\author{
Beata Grzywacz $^{1}$, Piotr Skórka ${ }^{\text {Corresp. } 2}$ \\ ${ }^{1}$ Institute of Systematics and Evolution of Animals, Polish Academy of Sciences, Kraków, Poland \\ 2 Institute of Nature Conservation, Polish Academy of Sciences, Kraków, Poland \\ Corresponding Author: Piotr Skórka \\ Email address: pskorka@iop.krakow.pl
}

Why do some species occur in small, restricted areas, while others are distributed globally? Environmental heterogeneity increases with area and so does the number of species. Hence, diverse biotic and abiotic conditions across large ranges may lead to specific adaptations that are often linked to a species' genome size and chromosome number. Therefore, a positive association between genome size and geographic range is anticipated. Moreover, high cognitive ability in organisms would be favored by natural selection to cope with the dynamic conditions within large geographic ranges. Here, we tested these hypotheses in birds-the most mobile terrestrial vertebrates-and accounted for the effects of various confounding variables, such as body mass, relative brain mass, and geographic latitude. Using phylogenetic generalized least squares and phylogenetic confirmatory path analysis, we demonstrated that range size is positively associated with bird genome size but probably not with chromosome number. Moreover, relative brain mass had no effect on range size, whereas body mass had a possible weak and negative effect, and range size was larger at higher geographic latitudes. However, our models did not fully explain the overall variation in range size. Hence, natural selection may impose larger genomes in birds with larger geographic ranges, although there may be additional explanations for this phenomenon. 
$5{ }^{1}$ Institute of Systematics and Evolution of Animals, Polish Academy of Sciences, Sławkowska 6 17, 31-016 Kraków, Poland

72 Institute of Nature Conservation, Polish Academy of Sciences, Mickiewicza 33, 31-120

8 Kraków, Poland

$9 *$ Corresponding author, emails: pskorka@iop.krakow.pl, skorasp@gmail.com

\section{Genome size versus geographic range size in birds}

\author{
Beata Grzywacz ${ }^{1}$, Piotr Skórka ${ }^{2 *}$
}

Abstract

Why do some species occur in small, restricted areas, while others are distributed globally? Environmental heterogeneity increases with area and so does the number of species. Hence, diverse biotic and abiotic conditions across large ranges may lead to specific adaptations that are often linked to a species' genome size and chromosome number. Therefore, a positive association between genome size and geographic range is anticipated. Moreover, high cognitive ability in organisms would be favored by natural selection to cope with the dynamic conditions within large geographic ranges. Here, we tested these hypotheses in birds - the most mobile terrestrial vertebrates - and accounted for the effects of various confounding variables, such as body mass, relative brain mass, and geographic latitude. Using phylogenetic generalized least squares and phylogenetic confirmatory path analysis, we demonstrated that range size is positively associated with bird genome size but probably not with chromosome number. Moreover, relative brain mass had no effect on range size, whereas body mass had a possible weak and negative effect, and range size was larger at higher geographic latitudes. However, our models did not fully explain the overall variation in range size. Hence, natural selection may impose larger genomes in birds with larger geographic ranges, although there may be additional explanations for this phenomenon. 
29

Key words: chromosome, distribution, evolution, gene, macroecology

Introduction

There is enormous variation in the sizes of species' geographic ranges (Gaston 2003).

There are several explanations for this, with leading hypotheses invoking traits such as body size (Cambefort 1994; Gaston \& Blackburn 2000), dispersal ability (Lester et al., 2007; Laube et al., 2013), and niche breadth (Garcia-Barros \& Romo Benito 2010). The increase in geographic range size is consistent with environmental variability (for example, climate), which is considered a major selective evolutionary force (Lee-Yaw \& Irwin 2012; Sayol et al., 2016; Liedtke et al., 2018). Therefore, species possess numerous traits for living in dynamic environments (Gaston \& Blackburn 2000; Zamudio et al., 2016). These traits have strong heritable components and are thus linked with gene number (Zhang et al., 2014). Hence, genome size could be an important predictor of a species' range size and could affect other species' traits subject to natural selection.

The evolution of genome size is multifaceted (Lefébure et al., 2017). According to the "selection hypothesis", the variation in genome size has consequences on organismal fitness and may thus be subject to selection (Gregory \& Hebert 1999; Petrov 2001). Corroborating this hypothesis, Hou \& Lin (2009) found a strong positive association between the log-transformed values of protein-coding gene number and genome size in eukaryotes and non-eukaryotes. In eukaryotes, genome size may be defined as the C-value, which is the amount of DNA per haploid genome and chromosome number. Genome size regulates the cell size associated with polyploidy, possibly leading to instantaneous shifts in the physiological tolerance and trait values (Levin 2002). Alternatively, according to the "junk DNA" hypothesis, the propagation of selfish intragenomic transposons and other mobile genetic elements leads to the accumulation of mutations throughout the genome, yielding a larger genome size (John \& Miklos 1988; Bennetzen \& Kellogg 1997). Indeed, organisms with larger genomes tend to have longer introns and more transposable elements than organisms with smaller genomes (Lynch \& Conery 2003; Charlesworth \& Barton 2004). 
These two hypotheses are often combined by postulating adaptive functions of this additional DNA, given that DNA abundance, rather than its contents, produces a direct and significant effect on the phenotype (Petrov 2001). For instance, a larger genome size may be an adaptive strategy, because it may directly or indirectly increase the nuclear and cellular volume (Cavalier-Smith 1978) and body size (Gregory 2005), buffer fluctuations in the enzyme concentrations, or protect the coding DNA from mutations (Hsu 1975; Janssen et al., 2018). Likewise, genome size is correlated with cell cycle complexity (Gregory 2002; Yu et al., 2019), basal metabolism (Vinogradov 1997), tissue differentiation, and developmental rate (Sessions \& Larson 1987; Xia 1995; Wyngaard et al., 2005). Arnqvist et al., (2015) showed that females with larger genomes laid more eggs and males with larger genomes fertilized more eggs in beetles.

The hypothesis regarding genome size versus geographic range size has already been tested in bacteria and plants. Bacteria with larger genomes are more likely to have wider environmental and geographic ranges than those with smaller genomes (Barberán et al., 2014; Choudoir et al., 2017). In contrast, while plant invasiveness is negatively associated with genome size but positively associated with chromosome number (and ploidy level), plant genome size is positively associated with chromosome number (Pandit et al., 2014). However, this hypothesis has not been tested in vertebrates.

In contrast to plants, genome size (C-value) may be weakly but positively correlated with chromosome number in animals (Vinogradov 1988; Elliott \& Gregory 2015). Chromosome number plays pivotal roles in speciation, sex determination, and developmental modes (King 1995; Warchałowska-Śliwa et al., 2011; Blackmon et al., 2017; Lucek 2018). Thus, chromosome number may also be positively associated with geographic range size (Guo et al., 2003; Martinez et al., 2017).

Birds are a unique and useful model group to test many evolutionary hypotheses. They have a limited genome size compared to other vertebrates, ranging from 1.15 to $1.62 \mathrm{pg}$ of DNA per haploid genome (Andrews et al., 2009). However, there is substantial variation in avian karyotypes; as such, the chromosomes are further divided into macro- and microchromosomes (Kretschmer et al., 2018; Degrandi et al., 2020). Avian genomic diversity covaries with adaptations to different life strategies and convergent evolution of traits (Zhang et al., 2014). Most birds possess the ability to fly; they are thus not as constrained by physical barriers, as are 
86

87

88

other organisms. Range size in birds is therefore often correlated with their dispersal ability (Böhning-Gaese et al., 2006; Laube et al., 2013). However, avian flight required massive changes (for light weight and increased energy efficiency) of all aspects, including the size of the genome (Zhang et al., 2014). In birds amount of DNA gained by transposable element expansion is counteracted by DNA loss from large segmental deletions (Kapusta et al., 2017; Zhang et al., 2014). Nevertheless, bird genome size is positively associated with the nuclear or cellular size and wing loading index, which is an indicator of adaptation for efficient flight (Andrews et al., 2009). Hence, a positive association between genome size and geographic range is anticipated in birds.

The alternative (but not mutually exclusive) hypothesis is that large geographic ranges favor enhanced cognitive skills, enabling survival in dynamic conditions across these ranges. Cognitive skills are linked to a large brain (Reader \& Laland 2002; Sol et al., 2005; Emery 2006) and seemingly to habitat generalism (Edmunds et al., 2016; Navarrete et al., 2016). Indeed, bird species exposed to greater environmental variation throughout their geographic range are likely to have larger brains (Sol et al., 2005; Sayol et al., 2016). Therefore, geographic range size may be positively correlated with brain size. In addition, brain size is strongly correlated with body size (Minias \& Podlaszczuk 2017). Thus, body size should always be considered a covariate in range size and genome studies, because there is a well-documented paradigm of overall positive association between body size and range size in animals (Gaston \& Blackburn 2000; Newsome et al., 2019).

Most bird lineages have diversified within rather restricted regions, and many tropical species are highly reluctant to cross unfamiliar habitats despite being able to fly (Gillies \& St. Clair 2010). In terms of their adaptability to a broad range of climates, it is often assumed that birds are constrained by niche conservatism, which appears to be asymmetrical. Ancient tropical groups cannot easily adapt to, or expand into, cold climates; however, groups that have evolved at high latitudes and are cold tolerant are actually thermally flexible and can easily adapt to new climates. They are therefore often the founders of breeding populations (and species proliferation) within the tropics (Smith et al., 2012; Khaliq et al., 2015; Winger et al., 2019). Thus, the range size of birds is expected to be larger at higher latitudes. 
To this end, in this study, we tested the hypothesis that genome size, chromosome

117 number, relative brain size, body size and latitude are positively associated with geographic

118 range size in birds. Efficient testing of the causality of such associations on a broad taxonomic

119 scale has proven difficult in the past due to the intercorrelations and phylogenetic non-

120 independence of these biological traits. Thus, we used phylogenetic generalized least squares

121 (PGLS) and phylogenetic confirmatory path analysis (PPA) to control for phylogeny and

122 evolutionary constraints while accounting for the multicollinearity of variables.

Methods

Data collection

Data on bird species' ranges were collected from BirdLife International (2019)

(http://datazone.birdlife.org/species/requestdis). Data were manipulated in QGIS 3 Noosa (QGIS

Development Team 2019). To calculate range areas, the Bonne equal-area transformation (ESRI: 54024) was applied. Only extant native ranges were used (Ravilious et al., 2015). Bird phylogenetic trees (Jetz et al., 2012, 2014) based on the constraints described by Hackett et al., (2008) were created in a nexus format online (http://birdtree.org). Sets of 1,000 trees were downloaded for three data subsets (see below). are no real-time data; this can yield some very problematic results (Hosner et al., 2015; Wang et al., 2017). However, newer avian megaphylogenies are available (Ksepka et al., 2020). The tree created by Ksepka et al., (2020) is based on the reanalysis of the supermatrix described by Burleigh et al., (2015). Ksepka et al., (2020) used constraints from the tree reported by Jarvis et al., (2014), which reflects analyses of approximately $40 \mathrm{Mbp}$ of aligned data and includes over 10,000 loci. The tree created by Ksepka et al., (2020) includes fewer species than that created by Jetz et al., (2012, 2014); however, we used a subset of species present in both to assess whether the results of statistical analyses differ between the two trees. (http://www.genomesize.com/search.php). This database contains both $\mathrm{C}$-value and chromosome number data. We gathered C-value data for 637 bird species. To complete chromosome number 
145 data, which was extremely limited, we also used data published by Kretschmer et al., (2018).

146 Body mass data were obtained from Wilman et al., (2014). Brain mass data were compiled from 147 three published sources (Fristoe et al., 2017; Minias \& Podlaszczuk 2017; Tsuboi et al., 2018).

148 Overall, both brain size and genome size data were available for 311 species. Finally, genome

149 size, chromosome number, brain size, and body size data were available for 65 species. All data 150 used in the analyses are available in Supplementary Material 1. Phylogenetic trees used in 151 analyses (see below) are attached as Supplmentary Material 2 and 3. Bird order and species 152 names follow Gill et al., (2020).

153

154

155

156

157

158

159

160

161

162

163

164

165

166

167

168

169

170

171

172

173

174

Data analysis

We computed three single-consensus trees using stringent consensus methods implemented in PAUP* 4.0 (Swofford 2003) from the three sets of 1,000 trees published by Jetz et al., $(2012,2014)$ downloaded from birdtree.org. The consensus methods used show the tree group sequences only if that grouping appears in all trees in the set. Three consensus trees were used in subsequent statistical analyses. The tree branch lengths were generated from the fitted branch lengths of the 1,000 input trees using the "consensus.edges" function of the phytools package in R (Revell 2012). The trees were visualized with Iroki (Moore et al., 2020) using the ggplot package in R (Wickham 2016), as shown in Figure S1 in Supplementary material 4. Moreover, the summary statistics on geographic range size, C-value and chromosome number were visualized in Figure 1 using a phylogenetic tree from Kimball et al. (2019). The species for which range size centroid is located below $30^{\circ}$ latitude are considered "tropical" species and are depicted in a different color from other species in visualizations.

We performed two sets of analyses: one based on the consensus trees published by Jetz et al., (2012, 2014) and another based on the tree published by Ksepka et al., (2020). We used PGLS models implemented in the nlme package (von Hardenberg \& Gonzalez-Voyer 2013; Pinheiro et al., 2019) and used the Brownian motion correlation structure of the model residuals to account for the phylogenetic dependence of species (Münkemüller et al., 2012). Brownian motion is a popular model in comparative biology, because it captures the potential trends of trait evolution under a reasonably wide range of scenarios (Münkemüller et al., 2012; Harmon 2019). Range sizes of the various bird species $\left(\mathrm{km}^{2}\right)$ was the dependent variable, while genome size (Cvalue) and chromosome number were the primary explanatory variables. We also included 
175 following covariates: body mass, relative brain mass, and geographic latitude (absolute values).

176 The relative brain mass residual in the PGLS model was not explained by body mass. These

177 variables are well linked to environmental variability and other species traits. Body mass and

178 relative brain mass were logarithmically transformed. The number of available data varied

179 among the explanatory variables; therefore, we built three models based on the trees published

180 by Jetz et al., $(2012,2014)$ for explaining range size variation in birds. The first model (637

181 species) included two explanatory variables, namely genome size and body mass. The second

182 model (311 species) included three explanatory variables, namely genome size, body mass, and

183 relative brain mass. The third model (65 species) included four explanatory variables, namely

184 genome size, chromosome number, body mass, relative brain mass and latitude. Each model was

185 tested against the null model (the model with the intercept alone) using the likelihood ratio test.

186 The Nagelkerke pseudo-R square, calculated in the companion package of $\mathrm{R}$, was used as the

187 measure of model fit (Mangiafico 2020).

188 Furthermore, we used PPA (von Hardenberg \& Gonzalez-Voyer 2013) based on

189 prespecified candidate path models to test for the effects of traits on range variation using the

190 "phylopath" package in R (van der Bijl 2018). This approach allowed us to compare the causal

191 hypotheses regarding the associations among traits, disentangling the direct effects from the

192 indirect ones, while correcting for the non-independence of the trait data due to common

193 ancestry (Santini et al., 2019). In addition, this model accounts for trait multicollinearity (Fig. 2)

194 better than multivariate linear models, because the variance of the response is partitioned among

195 fewer predictors (Gonzalez-Voyer \& von Hardenberg 2014). To build paths, we used data from

196 the third model, which contained all explanatory variables. The only difference was that we used

197 raw data on brain mass (logarithmically transformed) because the analysis enables to

198 disentangle the complex relations among variables. A total of 22 path model combinations were

199 built with different configurations of these variables. We used a set of hypotheses depicted by

200 directed acyclic graphs (Fig. 3) to minimize the number of models for testing (Gonzalez-Voyer

201 et al., 2016). The first set of models included the direct impact of each explanatory variable (Fig.

202 3), and the second set of models included indirect effects. We assumed that (1) the effect of

203 genome size may be mediated by chromosome number, (2) the effect of body mass may be

204 mediated by genome size, (3) the effect of brain mass may be indirect via relative brain mass,

205 and (4) the effect of geographic latitude may be mediated by body mass (Martin 1981). The third

Peer] reviewing PDF | (2020:07:50951:2:0:NEW 5 Jan 2021) 
206

207

208

209

210

211

212

213

214

215

216

217

218

219

220

221

222

223

224

225

226

227

228

229

230

231

232

233

set of models included more complex indirect associations (Fig. 3). Specifically, we assumed that the effect of body mass may be mediated by both genome size and chromosome number and that the effect of genome size may be mediated by chromosome number. Finally, these sets of models were tested against the null model. The sets of models were compared using the Cstatistic Information Criterion corrected for small sample sizes.

All analyses were repeated on the subset of species included in the latest phylogeny published by Ksepka et al., (2020). However, the sample size was lower. The first PGLS model (262 species) included two explanatory variables, namely genome size and body mass. The second model (254 species) included three explanatory variables, namely genome size, body mass, and relative brain mass. The third model ( 55 species) included four explanatory variables, namely genome size, chromosome number, body mass, relative brain mass and latitude. The PPA was based on the third model with 55 species.

\section{Results}

The first PGLS model showed that range size was positively associated with genome size and latitude but negatively associated with body mass (Table 1; Fig. 4). This model was statistically different from the null model $\left(\square^{2}=13.048, \mathrm{P}<0.001\right)$ and explained $4 \%$ of the total variation in range size. The second PGLS model also revealed that range size was positively associated with genome size but negatively associated with body mass, and not associated with relative brain mass and latitude (Table 1). This model was also statistically different from the null model $\left(\square^{2}=11.007, \mathrm{P}=0.008\right)$ and explained $6 \%$ of the total variation in range size.

Furthermore, the third PGLS model showed that range size was associated with genome size and body mass but not with chromosome number, relative brain mass and latitude (Table 1). This model was statistically different from the null model $\left(\square^{2}=12.738, \mathrm{P}=0.002\right)$ and explained $18 \%$ of the total variation in range size. In PPA, the models with indirect simple and indirect complex effects gained the highest support (Table 2). Based on the estimated coefficients, genome size had a significant and independent effect (confidence intervals not overlapping with zero) on range size (Fig. 5). 
Analysis based on the tree published by Ksepka et al., (2020) yielded similar results

235 (Table S1 and Fig. S2 in Supplementary Material 4). However, geographic latitude was

236 significant in all models examined. Moreover, in second model the relative brain mass had

237 positive effect on geographic range size (Table S1). In third model the number of chromosomes

238 had negative effect on the range size and the effect of the genome size was non-significant

239 (Table S1). However, the third model with all explanatory variables suffered due to small sample

240 size as revealed by running fourth model with the effect of genome size only (Table S1). Based

241 on these limited data, PPA indicated that range size was positively associated with geographic

242 latitude but negatively associated with chromosome number (Table S2 and Fig. S2 in

243 Supplementary Material 4).

Discussion

Large-scale patterns of spatial variation in species' geographic ranges are central to many fundamental questions in macroecology. However, the global nature of these patterns remains contentious. The present study confirmed our hypothesis that in birds, genome size is weakly but positively associated with geographic range size. Moreover, analysis on phylogenetic tree from Ksepka et al. (2020) showed that range size may be negatively correlated with chromosome numbers. Birds represent an example of a group in which genome size is correlated with active speciation. The amount of DNA gained by transposable element expansion is counteracted by DNA loss from large segmental deletions (Kapusta et al., 2017; Zhang et al., 2014). Thus, genome size regulation (Fisher et al., 2014) is perhaps more important to adaptation than genome size itself. Furthermore, the effect of genome size on geographic range size is not easy to predict, considering that it largely represents the dynamic balance between positive and negative selection on genome size. According to Lynch \& Conery (2003), the ineffectiveness of selection in species with a low effective population size is key to genome evolution. Large organisms have lower population sizes than small ones and hence a lower effective population size. The effective population size determines whether natural selection can maintain functional DNA sequences in the face of deleterious mutations. It is almost impossible for a deleterious mutation to spread when the effective population size is large; thus, it may prevent genome enlargement. 
264 documented (Gaston \& Blackburn 1996). Thus, these contrasting forces may be the reason

265 statistical models in this study explained only a small proportion of variation in range size.

266 However, our results are not different from the explained variances generally reported in

267 ecological research. According to Møller \& Jennions (2002), statistical models can explain

268 between $2.5 \%$ and $5.4 \%$ of variation in ecological studies. Moreover, there may be additional

269 explanations for the variation in range size in birds, which are mostly linked to environmental

270 constraints, such as climate, geographic location, and habitat (Orme et al., 2006; Laube et al.,

271 2014; Zhang et al., 2014; Sayol et al., 2016). Our results support prediction that the range size

272 increase with latitude. This finding is in line with the Rapoport's rule which states that there is a

273 positive latitudinal gradient in latitudinal range extent (Rapoport 1982; Stevens 1989). Despite

274 there is a criticism of this rule stating that this is a local phenomenon occurring only on the

275 northern Hemisphere above a latitude of about 40-50 N (Ruggiero \& Lawton 1998), there are

276 several studies supporting the Rapoport's rule, e.g. in amphibians (Whitton et al., 2012), birds

277 (Dyer et al., 2020) and mammals (Arita et al., 2005).

278

Interestingly, we found that body mass was negatively correlated with range size in

279

280

281

282

283

284

285

286

287

288

289

290

291

292

293

multivariate models. This result contradicts most previous findings, which are considered the paradigm of macroecology (Cambefort 1994; Gaston \& Blackburn 1996; Gaston \& Blackburn 2000). However, Gaston \& Blackburn (1996) used range size data of limited quality (generalized range maps); therefore, they may have greatly underestimated the range of several species with very small distributions. Hence, such an association should be investigated in more detail in additional taxa, because this knowledge may change our understanding of the role of body size in shaping range sizes. Body size depends on genome size (rather than vice versa); thus, genetic factors may be the primary causative variables, while body mass may be linked indirectly with species range.

Furthermore, we did not find effect of relative brain mass on range size, contrary to the previous reports of a positive association between environmental variation and brain size (Sayol et al., 2016). The effect was significant in one analysis based on Ksepka et al. (2020) but was not supported by PPA. Larger brains indicate higher cognitive ability (information processing) under strong selection (Reader \& Laland 2002; Sol et al., 2005). The possible explanation for this is that on a geographic scale, environmental variation may be too high for birds to adapt their

Peer) reviewing PDF | (2020:07:50951:2:0:NEW 5 Jan 2021) 
294 cognitive skills. In this case, adaptations to dynamic conditions would evolve, which may be

295 linked with genome size.

296

297 Study limitations

Several issues should be taken into consideration when interpreting our results. One of the great challenges in recent studies of macroecological patterns has been how to explain the

300

301

302

303

304

305

306

307

308

309

310

311

312

313

314

315

316

317

318

319

320

321

322

323

highly aggregated distribution of species with very small geographic ranges in specific tropical regions (for example, oroclines, locations near the edges of continental plates, or archipelagos [Rahbek et al., 2007, 2019; Jønsson et al., 2017]). Interestingly, 50\% of the avian species with very small geographic ranges are exclusively found at latitudes below $30^{\circ}$. Unfortunately, however, the genome data for these species are poorly represented. Hence, the results depend largely on geographic sampling. Our results are biased toward species with large-to-moderate geographic ranges, neglecting numerous tropical species with very small ranges. This bias may also explain the negative association between range size and body size. Another bias (or confounding factor) may be that flight ability (aerial foraging) has been found to correlate with a small genome size (Andrews et al., 2009; Kapusta et al., 2017); However, flight ability may also affect range size. As the genome size may be increased by the replication of transposable elements it may be also decreased by large deletions indicating that counteracting selective forces shape bird genome size (Kapusta et al., 2017; Zhang et al., 2014). Moreover, our sample size for analyses was limited by the availability of data on chromosome number. Thus, data on avian karyotypes and other traits potentially related to range should be included in future studies. Statistical methods we used assume that relationships are linear, which is not necessarily an optimal assumption (Quader et al., 2004). Phylogenetic comparative methods can fail to detect coevolution when the underlying relationships among traits are nonlinear (Quader et al., 2004). However, it is difficult to include nonlinear methods in phylogenetically corrected statistics, specifically PPA. We overcame this problem by logarithmic transformation of body mass and brain size data. Moreover, geographic latitude was included as an absolute value to allow for linear modeling.

We used two avian phylogenies. The first was proposed by Jetz et al., $(2012,2014)$ and included all taxa for which there are no real-time data. In that tree, there are parts of the topology 
324 for taxa with no data that have 100\% support (Hosner et al., 2015), which likely reflects the

325 difficulty of running the Markov chain Monte Carlo algorithm long enough to adequately sample

326 the posterior distribution when a large number of taxa are included. Meanwhile, the tree

327 presented by Ksepka et al., (2020) included fewer species, omitting some avian orders (such as

328 Casuariiformes and Ciconiiformes). Analysis based on this tree had a lower sample size and thus

329 a lower power, particularly when building models with all explanatory variables. Analyses with

330 both trees yielded slightly different results when the sample size was small. This indicate that

331 further research on avian phylogeny based on genome sequences with inclusion of as many taxa

332 as possible are required. In addition, species ranges are not constant, and the range data used

333 have other well-known limitations, however not better options exist at that scale of study.

Acknowledgments

336

We thank Alexandre Aleixo, Edward L. Braun, and Jon Fjeldså for constructive criticism on earlier versions of the manuscript. Beata Grzywacz was financed by the statutory funds of the Institute of Systematics and Evolution of Animals, Polish Academy of Sciences. Piotr Skórka was financed by the statutory funds of the Institute of Nature Conservation, Polish Academy of Sciences.

\section{References}

Andrews CB, Mackenzie SA, Gregory TR. 2009. Genome size and wing parameters in passerine 343 birds. Proceedings of the Royal Society B. 276: 55-61 DOI: https://doi.org/10.1098/rspb.2008.1012.

345 Arita HT, Rodríguez P, Vázquez-Domínguez E. 2005. Continental and regional ranges of North 346 American mammals: Rapoport's rule in real and null words. Journal of Biogeography 32: 961347 971 DOI: https://doi.org/10.1111/j.1365-2699.2005.01276.x.

348 Arnqvist G, Sayadi A, Immonen E, Hotzy C, Rankin D, Tuda M, Hjelmen CE, Johnston JS. 349 2015. Genome size correlates with reproductive fitness in seed beetles. Proceedings of the Royal 350 Society B. 282: 20151421 DOI: https://doi.org/10.1098/rspb.2015.1421. 
351 Barberán A, Ramirez KS, Leff JW, Bradford MA, Wall DH, Fierer N. 2014. Why are some 352 microbes more ubiquitous than others? Predicting the habitat breadth of soil bacteria. Ecology 353 Letters 17: 794-802 DOI: https://doi.org/10.1111/ele.12282.

354 Bennetzen JL, Kellogg EA. 1997. Do Plants Have a One-Way Ticket to Genomic Obesity? The 355 Plant Cell 9: 1509-1514 DOI: https://doi.org/10.1105/tpc.9.9.1509.

356 BirdLife International. 2019. Important Bird Areas factsheet: Isla Diego de Almagro.

357 Downloaded from http://www.birdlife.org (accessed 20 November 2019).

358

Blackmon H, Ross L, Bachtrog D. 2017. Sex Determination, Sex Chromosomes, and Karyotype Evolution in Insects. Journal Heredity 108: 78-93 DOI: https://doi.org/10.1093/jhered/esw047.

Böhning-Gaese K, Caprano T, van Ewijk K, Veith M. 2006. Range Size: Disentangling Current Traits and Phylogenetic and Biogeographic Factors. American Naturalist 167: 555-567 DOI: https://doi.org/10.1086/501078.

Burleigh JG, Kimball RT, Braun EL (2015) Building the avian tree of life using a large-scale, sparse supermatrix. Molecular Phylogenetics and Evolution 84: 53-63 DOI: https://doi.org/10.1016/j.ympev.2014.12.003.

Cambefort Y. 1994. Body-size, abundance, and geographical distribution of Afrotropical dung beetles (Coleoptera, Scarabaeidae). Acta Oecologica 15: 165-179.

Cavalier-Smith T. 1978. Nuclear volume control by nucleoskeletal DNA, selection for cell volume and cell growth rate, and the solution of the DNA C-value paradox. Journal of Cell Science 34: 247-278.

Charlesworth B, Barton N. 2004. Genome Size: Does Bigger Mean Worse? Current Biology 14: R233-R235 DOI: https://doi.org/10.1016/j.cub.2004.02.054.

Choudoir MJ, Barberán A, Menninger HL, Dunn RR, Fierer N. 2018. Variation in range size and dispersal capabilities of microbial taxa. Ecology 99: 322-334 DOI: https://doi.org/10.1002/ecy.2094. 
376 Degrandi TM, Barcellos SA, Costa AL, Garnero ADV, Hass I, Gunski RJ. 2020. Introducing the 377 Bird Chromosome Database: An Overview of Cytogenetic Studies in Birds. Cytogenetic and 378 Genome Research 160: 199-205 DOI: https://doi.org/10.1159/000507768.

379 Dyers EE, Redding DW, Cassey P, Collen B, Blackburn TM. 2020. Evidence for Rapoport's rule 380 and latitudinal patterns in the global distribution and diversity of alien bird species. Journal of 381 Biogeography 47: 1362-1372 DOI: https://doi.org/10.1111/jbi.13825.

382

383

384

385

386

387

388

389

390

391

392

393

394

395

396

397

398

399

400

401

Edmunds NB, Laberge F, McCann KS. 2016. A role for brain size and cognition in food webs. Ecology Letters 19: 948-955 DOI: https://doi.org/10.1111/ele.12633.

Elliott TA, Gregory TR. 2015. What's in a genome? The C-value enigma and the evolution of eukaryotic genome content. Philosophical Transactions of the Royal Society B. 370: 20140331 DOI: https://doi.org/10.1098/rstb.2014.0331.

Emery NJ. 2006. Cognitive ornithology: the evolution of avian intelligence. Philosophical Transactions of the Royal Society B. 361: 23-43 DOI: https://doi.org/10.1098/rstb.2005.1736.

Fristoe TS, Iwaniuk AN, Botero CA. 2017. Big brains stabilize populations and facilitate colonization of variable habitats in birds. Nature Ecology and Evolution 1: 1706-1715 DOI: https://doi.org/10.1038/s41559-017-0316-2.

Garcia-Barros E, Romo Benito H. 2010. The relationship between geographic range size and life history trait: is biogeographic history uncovered? A test using the Iberian butterflies Ecography 33: 392-401 DOI: https://doi.org/10.1111/j.1600-0587.2010.06269.x.

Gaston KJ. 2003. The Structure and Dynamics of Geographic Ranges. Oxford: Oxford University Press.

Gaston KJ, Blackburn TM. 1996. Global Scale Macroecology: Interactions between Population Size, Geographic Range Size and Body Size in the Anseriformes. Journal of Animal Ecology 65: 701-714 DOI: https://doi.org/10.2307/5669.

Gaston KJ, Blackburn TM. 2000. Pattern and Process in Macroecology. Oxford: Blackwell Publishing. 
402 Gill F, Donsker D, Rasmussen P. 2020. IOC World Bird List (v10.2). DOI:

403 10.14344/IOC.ML.10.2. https://www.worldbirdnames.org/

404

405 Gillies CS, St. Clair CC. 2010. Functional responses in habitat selection by tropical birds moving 406 through fragmented forest. Journal of Applied Ecology 47:182-190. DOI:

407 https://doi.org/10.1111/j.1365-2664.2009.01756.x.

408 Gonzalez-Voyer A, Gonzalez-Suarez M, Vila C, Revilla E. 2016 Larger brain size indirectly 409 increases vulnerability to extinction in mammals. Evolution 70: 1364-1375 DOI:

410 https://doi.org/10.1111/evo.12943.

411 Gonzalez-Voyer A, von Hardenberg A. 2014. An introduction to phylogenetic path analysis. In:

412 Garamszegi LZ, ed. Modern Phylogenetic Comparative Methods and Their Application in

413 Evolutionary Biology. Berlin, Heidelberg: Springer-Verlag, 201-229.

414 Gregory TR. 2002 Genome size and developmental complexity. Genetica 115: 131-146 DOI:

415 https://doi.org/10.1023/A:1016032400147.

416 Gregory TR. (ed) 2005. The Evolution of the Genome. San Diego: Elsevier.

417 Gregory TR, Hebert PD. 1999. The modulation of DNA content: proximate causes and ultimate 418 consequences. Genome Research 9: 317-324 DOI: https://doi.org/10.1101/gr.9.4.317

419 Guo QF, Kato M, Ricklefs RE. 2003. Life history, diversity and distribution: a study of Japanese 420 pteridophytes. Ecography 26: 129-138 DOI: https://doi.org/10.1034/j.1600-0587.2003.03379.x.

421 Hackett SJ, Kimball RT, Reddy S, Bowie RCK, Braun EL, Braun MJ, Chojnowski JL, Cox WA, 422 Han K-L, Harshman J, Huddleston CJ, Marks BD, Miglia KJ, Moore WS, Sheldon FH, 423 Steadman DW, Witt CC, Yuri T. 2008. A Phylogenomic Study of Birds Reveals Their 424 Evolutionary History. Science 320: 1763-1768 DOI: https://doi.org/10.1126/science.1157704.

425 Harmon LJ. 2019. Phylogenetic Comparative Methods. CC-BY 2019. Available from:

426 https://lukejharmon.github.io/pcm/pdf/phylogeneticComparativeMethods.pdf.

427 Hosner PA, Braun EL, Kimball RT. 2015. Land connectivity changes and global cooling shaped 428 the colonization history and diversification of New World quail (Aves: Galliformes: 
429 Odontophoridae). Journal of Biogeography 42: 1883-1895 DOI:

430 https://doi.org/10.1111/jbi.12555.

431 Hou Y, Lin S. 2009. Distinct Gene Number-Genome Size Relationships for Eukaryotes and Non432 Eukaryotes: Gene Content Estimation for Dinoflagellate Genomes. PLoS ONE 4(9): e6978 DOI: 433 https://doi.org/10.1371/journal.pone.0006978.

434 Hsu TC. 1975. A possible function of constitutive heterochromatin: the bodyguard hypothesis. 435 Genetics 79 (Suppl.): 137-150.

436 Janssen A, Colmenares SU, Karpen GH. 2018. Heterochromatin: Guardian of the genome.

437 Annual Review of Cell and Developmental Biology 34: 265-288 DOI:

438 https://doi.org/10.1146/annurev-cellbio-100617-062653.

439 Jarvis ED, Mirarab S, Aberer AJ, Li B, Houde P, Li C, Ho SYW, Faircloth BC, Nabholz B, 440 Howard JT, Suh A, Weber CC, da Fonseca RR, Li J, Zhang F, Li H, Zhou L, Narula N, Liu L, 441 Ganapathy G, Boussau B, Bayzid MS, Zavidovych V, Subramanian S, Gabaldon T, Capella442 Gutierrez S, Huerta-Cepas J, Rekepalli B, Munch K, Schierup M, Lindow B, Warren WC, Ray 443 D, Green RE, Bruford MW, Zhan X, Dixon A, Li S, Li N, Huang Y, Derryberry EP, Bertelsen 444 MF, Sheldon FH, Brumfield RT, Mello CV, Lovell PV, Wirthlin M, Schneider MPC, Prosdocimi 445 F, Samaniego JA, Velazquez AMV, Alfaro-Nunez A, Campos PF, Petersen B, Sicheritz-Ponten 446 T, Pas A, Bailey T, Scofield P, Bunce M, Lambert DM, Zhou Q, Perelman P, Driskell AC, 447 Shapiro B, Xiong Z, Zeng Y, Liu S, Li Z, Liu B, Wu K, Xiao J, Yinqi X, Zheng Q, Zhang Y, 448 Yang H, Wang J, Smeds L, Rheindt FE, Braun M, Fjeldsa J, Orlando L, Barker FK, Jonsson KA, 449 Johnson W, Koepfli K-P, O’Brien S, Haussler D, Ryder OA, Rahbek C, Willerslev E, Graves 450 GR, Glenn TC, McCormack J, Burt D, Ellegren H, Alstrom P, Edwards SV, Stamatakis A, 451 Mindell DP, Cracraft J, Braun EL, Warnow T, Jun W, Gilbert MTP, Zhang G. 2014. Whole452 genome analyses resolve early branches in the tree of life of modern birds. Science 346:13204531331 DOI: https://doi.org/10.1126/science.1253451.

454 Jetz W, Thomas GH, Joy JB, Hartmann K, Mooers AO. 2012. The global diversity of birds in 455 space and time. Nature 491: 444-448 DOI: https://doi.org/10.1038/nature11631. 
456 Jetz W, Thomas GH, Joy JB, Hartmann K, Redding D, Mooers AO. 2014. Global Distribution 457 and Conservation of Evolutionary Distinctness in Birds. Current Biology 24: 1-12 DOI: 458 https://doi.org/10.1016/j.cub.2014.03.011.

459 John B, Miklos GLG. 1988. The Eukaryotic Genome in Development and Evolution, Allen \& 460 Unwin.

461 Jønsson K. A. Borregaard M. K. Carstensen D. W. Hansen L. A. Kennedy J. D. Machac A. 462 Marki P. Z. Fjeldså J. Rahbek C. 2017. Biogeography and biotic assembly of Indo-Pacific 463 corvoid passerine bird diversity. Annual Review in Ecology, Evolution and Systematics 48: 231464 253 DOI: https://doi.org/10.1146/annurev-ecolsys-110316-022813.

465 Kapusta A, Suh A, Feschotte C. 2017. Dynamics of genome size evolution in amniotes. Proceedings of the National Academy of Sciences USA. 114 (8): E1460-E1469 DOI: https://doi.org/10.1073/pnas.1616702114.

Kimball RT, Oliveros CH, Wang N, White ND, Barker FK, Field DJ, Ksepka DT, Chesser RT, Moyle RG, Braun MJ, Brumfield RT, Faircloth BC, Smith BT, Braun EL. 2019. A Phylogenomic Supertree of Birds. Diversity 11: 109 DOI: https://doi.org/10.3390/d1 1070109.

King M. 1995 Species Evolution. Cambridge: Cambridge University Press.

Khaliq I, Fritz SA, Prinzinger R, Pfenninger M, Böhning-Gaese K, Hof C. 2015. Global conservatism only in the tropics. Journal of Biogeography 42: 2187-2196 DOI: https://doi.org/10.1111/jbi.12573. https://doi.org/10.3390/genes9040181.

479 Ksepka DT, Balanoff AM, Smith NA, Bever GS, Bhullar B-AS, Bourdon E, Braun EL, Burleigh 480 JG, Clarke JA, Colbert MW, Corfield JR, Degrange FJ, De Pietri VL, Early CM, Field DJ, 481 Gignac PM, Gold MEL, Kimball RT, Kawabe S, Lefebvre L, Marugán-Lobón J, Mongle CS, 482 Morhardt A, Norell MA, Ridgely RC, Rothman RS, Scofield RP, Tambussi CP, Torres CR, van 483 Tuinen M, Walsh SA, Watanabe A, Witmer LM, Wright AK, Zanno LE, Jarvis ED, Smaers JB. 
484 2020. Tempo and Pattern of Avian Brain Size Evolution. Current Biology 30: 2026-2036.e3

485 DOI: https://doi.org/10.1016/j.cub.2020.03.060.

486 Laube I, Korntheuer H, Schwager M, Trautmann S, Rahbek C, Böhning-Gaese K. 2013.

487 Towards a more mechanistic understanding of traits and range sizes. Global Ecology and

488 Biogeography 22: 233-241 DOI: https://doi.org/10.1111/j.1466-8238.2012.00798.x.

489 Lee-Yaw JA, Irwin DE. 2012. Large geographic range size reflects a patchwork of divergent 490 lineages in the long-toed salamander (Ambystoma macrodactylum). Journal of Evolutionary 491 Biology 25: 2276-2287 DOI: https://doi.org/10.1111/j.1420-9101.2012.02604.x.

492 Lefébure T, Morvan C, Malard F, François C, Konecny-Dupré L, Guéguen L, Weiss-Gayet M, 493 Seguin-Orlando A, Ermini L, Sarkissian CD, Charrier NP, Eme D, Mermillod-Blondin F, Duret 494 L, Vieira C, Orlando L, Douady CJ. 2017. Less effective selection leads to larger genomes. 495 Genome Research 27: 1016-1028 DOI: https://doi.org/10.1101/gr.212589.116.

496 Lester SE, Ruttenberg BI, Gaines SD, Kinlan BP. 2007. The relationship between dispersal 497 ability and geographic range size. Ecology Letters 10: 745-758 DOI: 498 https://doi.org/10.1111/j.1461-0248.2007.01070.x.

499 Levin DA. 2002. The role of chromosomal change in plant evolution. Oxford, UK: Oxford 500 University Press.

501 Liedtke HC, Gower DJ, Wilkinson M, Gomez-Mestre I. 2018. Macroevolutionary shift in the 502 size of amphibian genomes and the role of life history and climate. Nature Ecology and 503 Evolution 2: 1792 DOI: https://doi.org/10.1038/s41559-018-0674-4.

504 Lucek K. 2018. Evolutionary Mechanisms of Varying Chromosome Numbers in the Radiation of 505 Erebia Butterflies. Genes 9(3): 166 DOI: https://doi.org/10.3390/genes9030166.

506 Lynch M, Conery JS. 2003. The Origins of Genome Complexity. Science 302: 1401-1404 DOI: 507 https://doi.org/10.1126/science. 1089370.

508 Mangiafico S. 2020. rcompanion: Functions to Support - Extension Education Program 509 Evaluation. R package version 2.3.25. https://CRAN.R-project.org/package=rcompanion. 
510 Martin RD. 1981. Relative brain size and basal metabolic rate in terrestrial vertebrates. Nature

511 293: 57-60 DOI: https://doi.org/10.1038/293057a0.

512 Martinez PA, Jacobina UP, Fernandes RV, Brito C, Penone C, Amado TF, Fonseca CR, Bidau

513 CJ. 2017. A comparative study on karyotypic diversification rate in mammals. Heredity 118(4):

514 366-373 DOI: https://doi.org/10.1038/hdy.2016.110.

515 Minias P, Podlaszczuk P. 2017. Longevity is associated with relative brain size in birds. Ecology 516 and Evolution 7: 3558-3566 DOI: https://doi.org/10.1002/ece3.2961.

517 Moore RM, Harrison AO, McAllister SM, Polson SW, Wommack KE. 2020. Iroki: automatic

518 customization and visualization of phylogenetic trees. PeerJ 8: e8584 DOI:

519 https://doi.org/10.7717/peerj.8584.

520 Møller AP, Jennions MD. 2002. How much variance can be explained by ecologists and 521 evolutionary biologists? Oecologia 132: 492-500 DOI: https://doi.org/10.1007/s00442-002$522 \quad 0952-2$.

523 Münkemüller T, Lavergne S, Bzeznik B, Dray S, Jombart T, Schiffers K, Thuiller W. 2012. How 524 to measure and test phylogenetic signal. Methods in Ecology and Evolution 3: 743-756 DOI: 525 https://doi.org/10.1111/j.2041-210X.2012.00196.x.

526 Navarrete AF, Reader SM, Street SE, Whalen A, Laland KN. 2016. The coevolution of 527 innovation and technical intelligence in primates. Philosophical Transactions of the Royal 528 Society B. 371: 20150186 DOI: https://doi.org/10.1098/rstb.2015.0186.

529 Newsome TM, Wolf C, Nimmo DG, Keller Kopf R, Ritchie EG, Smith FA, Ripple WJ. 2019. 530 Constraints on vertebrate range size predict extinction risk. Global Ecology and Biogeography 531 29: 76-86 DOI: https://doi.org/10.1111/geb.13009.

532 Orme CDL, Davies RG, Olson VA, Thomas GH, Ding T-S, Rasmussen PC, Ridgely RS, 533 Stattersfield AJ, Bennett PM, Owens IPF, Blackburn TM, Gaston KJ. 2006. Global patterns of 534 geographic range size in birds. PLoS Biology 4(7): e208 DOI:

535 https://doi.org/10.1371/journal.pbio. 0040208.

536 Petrov DA. 2001. Evolution of genome size: new approaches to an old problem. Trends in 537 Genetics 17: 23-28 DOI: https://doi.org/10.1016/s0168-9525(00)02157-0. 
538 Pinheiro J, Bates D, DebRoy S, Sarkar D, R Core Team. 2019. nlme:

539 Linear and Nonlinear Mixed Effects Models. R package version 3.1-142,

540 https://CRAN.R-project.org/package=nlmePandit MK, White SM, Pocock MJO. 2014. The

541 contrasting effects of genome size, chromosome number and ploidy level on plant invasiveness:

542 a global analysis. New Phytologist 203: 697-703 DOI: https://doi.org/10.1111/nph.12799.

543 QGIS Development Team. 2019. QGIS Geographic Information System. Open Source

544 Geospatial Foundation Project. http://qgis.osgeo.org.

545 Quader S, Isvaran K, Hale RE, Miner BG, Seavy NE. 2004. Nonlinear relationships and 546 phylogenetically independent contrasts. Journal of Evolutionary Biology 17: 709-715 DOI:

547 https://doi.org/10.1111/j.1420-9101.2004.00697.x

548 Rahbek C, Gotelli NJ, Colwell RK, Entsminger GL, Rangel TFLVB, Graves GR. 2007.

549 Predicting continental-scale patterns of bird species richness with spatially explicit models.

550 Proceedings of the Royal Society B: Biological Sciences 274: 165-174 DOI:

551 https://doi.org/10.1098/rspb.2006.3700.

552 Rahbek C, Borregaard MK, Colwell RK, Dalsgaard B, Holt BG, Morueta-Holme N, Nogues-

553 Bravo D, Whittaker RJ, Fjeldså J. 2019. Humboldt's enigma: What causes global patterns of

554 mountain biodiversity? Science 365: 1108-1113 DOI: https://doi.org/10.1126/science.aax0149.

555 Rapoport EH. 1982. Aerography: Geographical Strategies of Species. New York> Pergamon 556 press.

557 Ravilious C, Goodman L, Bodin B, Runsten L, Osti M. 2015. Using spatial information to

558 support decisions on safeguards and multiple benefits for REDD+. Step-by-step tutorial v1.0:

559 Extracting and processing IUCN Red List species data using a vector method in a combination of 560 QGIS 1.8 and 2.8. Prepared on behalf of the UN-REDD Programme. UNEP World Conservation 561 Monitoring Centre, Cambridge, UK.

562 Reader SM, Laland KN. 2002 Social intelligence, innovation, and enhanced brain size in 563 primates. Proceedings of the National Academy of Sciences USA 99(7): 4436-4441 DOI:

564 https://doi.org/10.1073/pnas.062041299. 
565 Revell LJ. 2012. phytools: An R package for phylogenetic comparative biology (and other 566 things). Methods in Ecology and Evolution 3: 217-223 DOI: https://doi.org/10.1111/j.2041567 210X.2011.00169.x.

568 Ruggiero A, Lawton JH. 1998. Are there latitudinal and altidudinal Rapoport effects in the 569 geographic ranges of Andean passerine birds? Biological Journal of the Linnean Society 63: 570 283-304 DOI: https://doi.org/10.1006/bij1.1997.0190.

571 Santini L, González-Suárez M, Russo D, Gonzalez-Voyer A, von Hardenberg A, Ancillotto L.

572 2019. One strategy does not fit all: Determinants of urban adaptation in mammals. Ecology 573 Letters 22: 365-376.

574 Sayol F, Maspons J, Lapiedra O, Iwaniuk AN, Székely T, Sol D. 2016. Environmental variation 575 and the evolution of large brains in birds. Nature Communications 7: 13971 DOI:

576 https://doi.org/10.1038/ncomms13971.

577 Sessions SK, Larson A. 1987. Developmental correlates of genome size in Plethodontid 578 salamanders and their implications for genome evolution. Evolution 41: 1239-1251 DOI: 579 https://doi.org/10.1111/j.1558-5646.1987.tb02463.x.

580 Smith BT, Bryson RW, Houston DD, Klicka J. 2012. An asymmetry in niche conservatism 581 contributes to the latitudinal species diversity gradient in New World vertebrates. Ecology 582 Letters 15: 1318-1325 DOI: https://doi.org/10.1111/j.1461-0248.2012.01855.x.

583 Sol D, Duncan RP, Blackburn TM, Cassey P, Lefebvre L. 2005. Big brains, enhanced cognition, 584 and response of birds to novel environments. Proceedings of the National Academy of Sciences 585 USA 102: 5460-5465 DOI: https://doi.org/10.1073/pnas.0408145102.

586 Stevens GC. 1989. The latitudinal gradient in geographical range: how so many species coexist 587 in the tropics. The American Naturalist 133: 240-256.

588 Swofford DL. 2003. PAUP*. Phylogenetic Analysis Using Parsimony (*and Other Methods). 589 Version 4. Sinauer Associates, Sunderland, Massachusetts.

590 Tsuboi MW, Van der B, Kopperud BT, Erritzøe J, Voje KL, Kotrschal A, Yopak KE, Collin SP, 591 Iwaniuk AN, Kolm N. 2018. Breakdown of brain-body allometry and the encephalization of 
592 birds and mammals. Nature Ecology and Evolution 2: 1492-1500 DOI:

593 https://doi.org/10.1038/s41559-018-0632-1.

594 van der Bijl W. 2018. phylopath: Easy phylogenetic path analysis in R. PeerJ 6: e4718 DOI:

595 https://doi.org/10.7717/peerj.4718.

596 Vinogradov AE. 1997. Nucleotypic effect in homeotherms: body-mass independent resting

597 metabolic rate of passerine birds is related to genome size. Evolution 51: 220-225 DOI:

598 https://doi.org/10.1111/j.1558-5646.1995.tb04451.x.

599 Vinogradov AE. 1998. Genome size and GC-percent in vertebrates as determined by flow

600 cytometry: the triangular relationship. Cytometry 31: 100-109 DOI:

601 https://doi.org/10.1002/(sici)1097-0320(19980201)31:2<100::aid-cyto5>3.0.co;2-q.

602 von Hardenberg A, Gonzalez-Voyer A. 2013. Disentangling evolutionary cause-effect 603 relationships with phylogenetic confirmatory path analysis. Evolution 67: 378-387 DOI:

604 https://doi.org/10.1111/j.1558-5646.2012.01790.x.

605 Wang N, Kimball RT, Braun EL, Liang B, Zhang Z. 2017. Ancestral range reconstruction of 606 Galliformes: the effects of topology and taxon sampling. Journal of Biogeography 44: 122-135 607 DOI: https://doi.org/10.1111/jbi.12782.

608 Warchałowska-Śliwa E, Maryańska-Nadachowska A, Grzywacz B, Karamysheva T, Lehmann 609 AW, Lehmann GUC, Heller K-G. 2011. Changes in the numbers of chromosomes and sex 610 determination system in bushcrickets of the genus Odontura (Orthoptera, Tettigoniidae, 611 Phaneropterinae). European Journal of Entomology 108: 183-195 DOI:

612 https://doi.org/10.14411/eje.2011.025.

613 Whitton FJS, Purvis A, Orme CDL, Olalla-Tarraga MA. 2012. Understanding global patterns in 614 amphibian geographic range size: Does Rapoport rule? Global Ecology and Biogeography 21: 615 179-190 DOI: https://doi.org/10.1111/j.1466-8238.2011.00660.x.

616 Wickham H. 2016. ggplot2: Elegant Graphics for Data Analysis. Springer-Verlag New York. 617 ISBN 978-3-319-24277-4, https://ggplot2.tidyverse.org. 
618 Wilman H, Belmaker J, Simpson J, de la Rosa C, Rivadeneira M.M, Jetz W. 2014. EltonTraits

619 1.0: Species-level foraging attributes of the world's birds and mammals. Ecology 95: 2027

620 DOI:10.1890/13-1917.1.

621 Winger BM, Auteri GG, Pegan TM, Weeks BC. 2019. A long winter for the Red Queen:

622 Rethinking the evolution of seasonal migration. Biological Reviews 94: 737-753 DOI:

623 https://doi.org/10.1111/brv.12476.

624 Wyngaard GA, Rasch EM, Manning NM, Gasser K, Domangue R. 2005. The relationship

625 between genome size, development rate, and body size in copepods. Hydrobiologia 532: 123-

626137 DOI: https://doi.org/10.1007/s10750-004-9521-5.

627 Xia X. 1995. Body temperature, rate of biosynthesis, and evolution of genome size. Molecular

628 Biology and Evolution 12: 834-842 DOI:

629 https://doi.org/10.1093/oxfordjournals.molbev.a040260.

630 Yu JP, Liu W, Mai CL, Liao WB. 2019. Genome size variation is associated with life-history

631 traits in birds. Journal of Zoology 310: 255-260 DOI: https://doi.org/10.1111/jzo.12755.

632 Zamudio KR, Bell RC, Mason NA. 2016. Phenotypes in phylogeography: species' traits,

633 environmental variation, and vertebrate diversification. Proceedings of the National Academy of

634 Sciences USA 113: 8041-8048.

635 Zhang G, Li C, Li Q, Li B, Larkin DM, Lee C, Storz JF, Antunes A, Greenwold MJ, Meredith

636 RW, Odeen A, Cui J, Zhou Q, Xu L, Pan H, Wang Z, Jin L, Zhang P, Hu H, Yang W, Hu J, Xiao

637 J, Yang Z, Liu Y, Xie Q, Yu H, Lian J, Wen P, Zhang F, Li H, Zeng Y, Xiong Z, Liu S, Zhou L,

638 Huang Z, An N, Wang J, Zheng Q, Xiong Y, Wang G, Wang B, Wang J, Fan Y, da Fonseca RR,

639 Alfaro-Nunez A, Schubert M, Orlando L, Mourier T, Howard JT, Ganapathy G, Pfenning A,

640 Whitney O, Rivas MV, Hara E, Smith J, Farre M, Narayan J, Slavov G, Romanov MN, Borges

641 R, Machado JP, Khan I, Springer MS, Gatesy J, Hoffmann FG, Opazo JC, Hastad O, Sawyer

642 RH, Kim H, Kim K-W, Kim HJ, Cho S, Li N, Huang Y, Bruford MW, Zhan X, Dixon A,

643 Bertelsen MF, Derryberry E, Warren W, Wilson RK, Li S, Ray DA, Green RE, O’Brien SJ,

644 Griffin D, Johnson WE, Haussler D, Ryder OA, Willerslev E, Graves GR, Alstrom P, Fjeldsa J,

645 Mindell DP, Edwards SV, Braun EL, Rahbek C, Burt DW, Houde P, Zhang Y, Yang H, Wang J,

646 Jarvis ED, Gilbert MTP, Wang J, Ye C, Liang S, Yan Z, Zepeda ML, Campos PF, Velazquez

Peer] reviewing PDF | (2020:07:50951:2:0:NEW 5 Jan 2021) 
647 AMV, Samaniego JA, Avila-Arcos M, Martin MD, Barnett R, Ribeiro AM, Mello CV, Lovell 648 PV, Almeida D, Maldonado E, Pereira J, Sunagar K, Philip S, Dominguez-Bello MG, Bunce M, 649 Lambert D, Brumfield RT, Sheldon FH, Holmes EC, Gardner PP, Steeves TE, Stadler PF, Burge 650 SW, Lyons E, Smith J, McCarthy F, Pitel F, Rhoads D, Froman DP. 2014. Comparative 651 Genomics Reveals Insights into Avian Genome Evolution and Adaptation. Science 346: 13116521320 DOI: https://doi.org/10.1126/science.1251385.

653

654

655

656

657

658

659

660 
Figure 1

A summary statistics of the studied variables

The distirubution of bird (A) genome size, (B) number of chromosomes, and (C) geographic range size on the phylogenetic tree. The phylogenetic tree is from Kimball et al. (2019). Bars are means with standard deviations. Sample size (number of species) is given next to each bar. NA indicates that data was not available. Sample size for the geographic range size is the same as for the genome size.
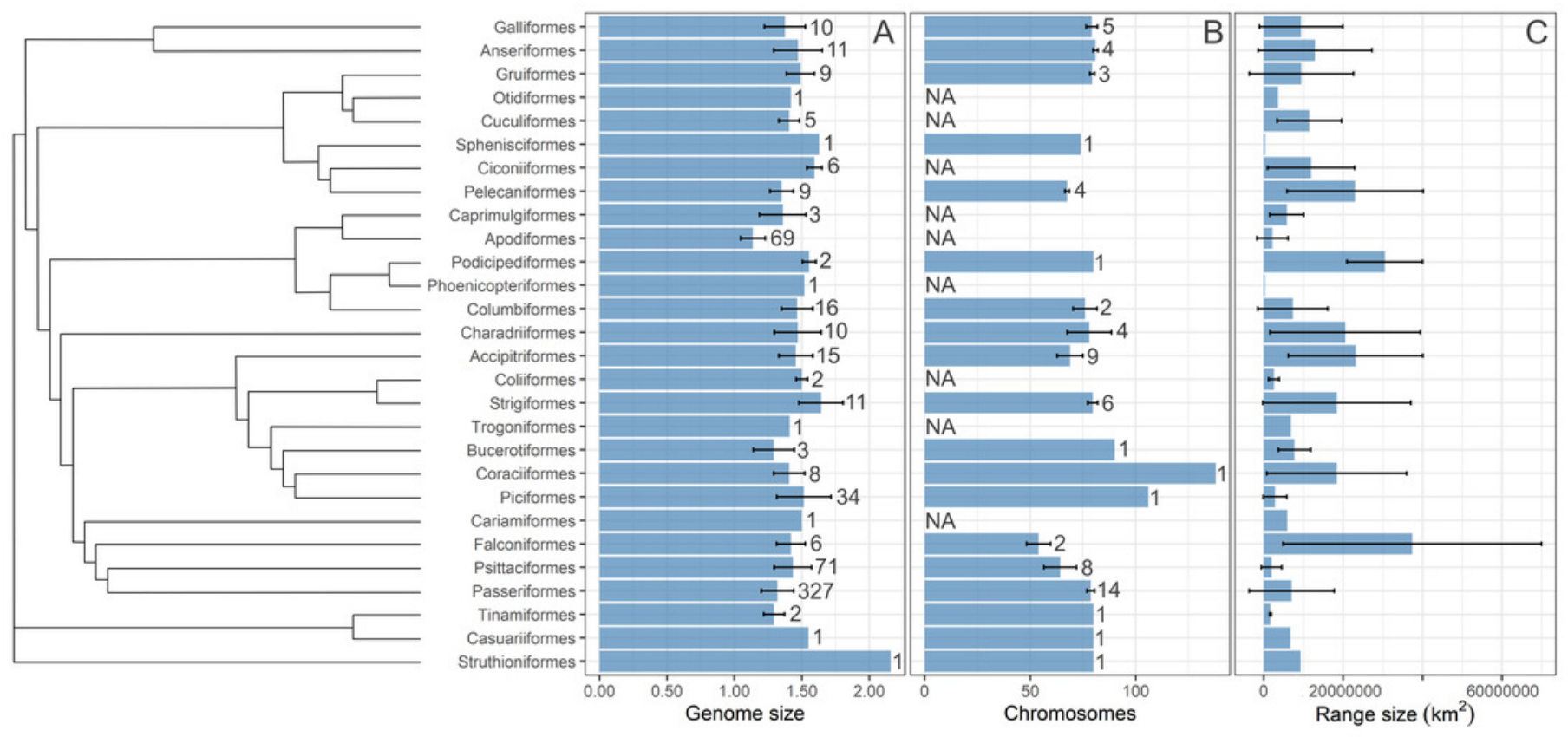


\section{Figure 2}

Associations among the explanatory variables revealed by phylogenetic generalized least squares (fitted red line)

Size of the dots is scaled according to geographic range size.The species for which geographic range centroid is located below $30^{\circ}$ latitude are considered "tropical" species (orange dots) in contrast to other species (blue dots). Dots are transparent for better visibility of overlapping data. Statistical significance is presented along with sample size 

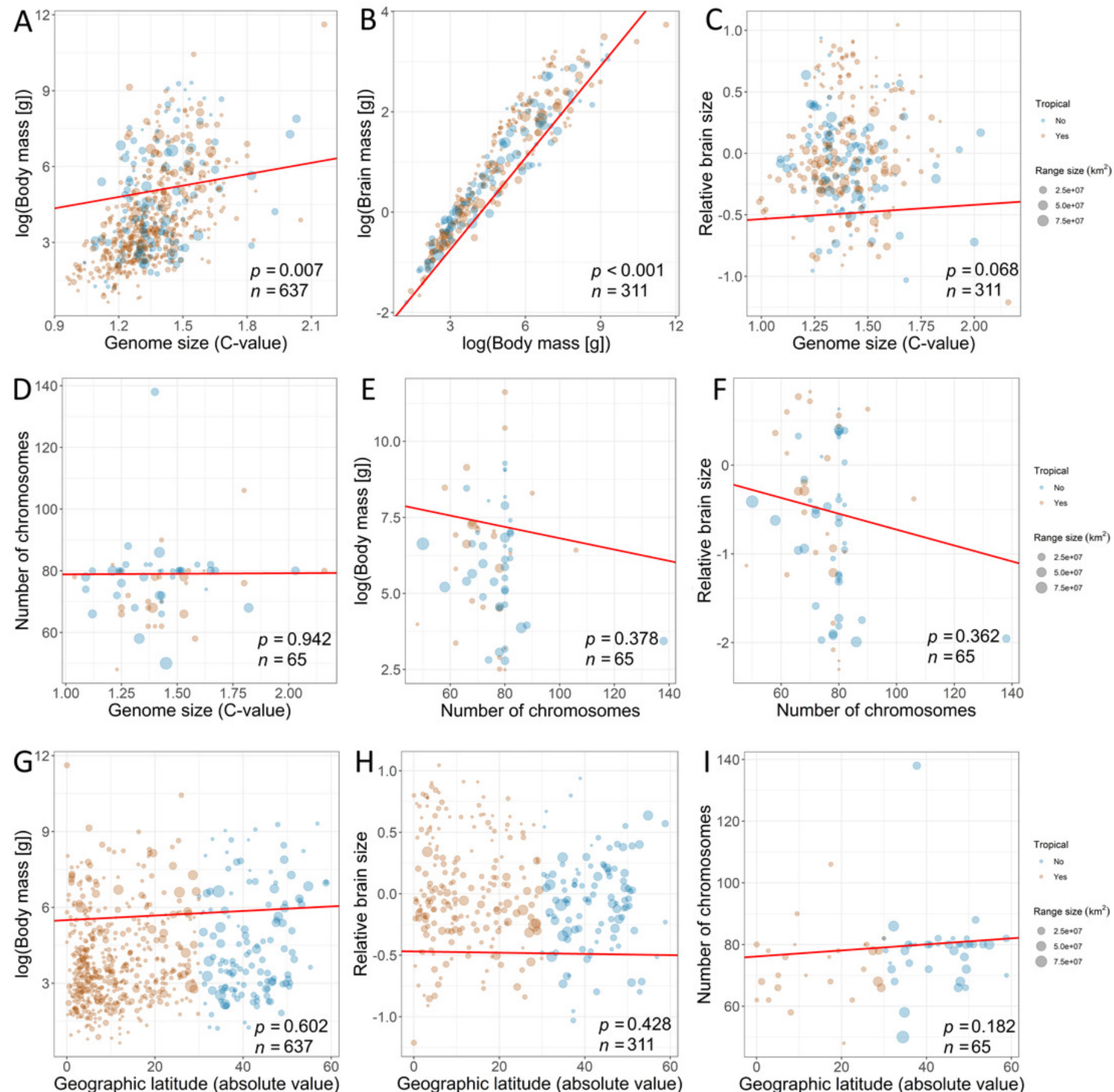

Geographic latitude (absolute value)

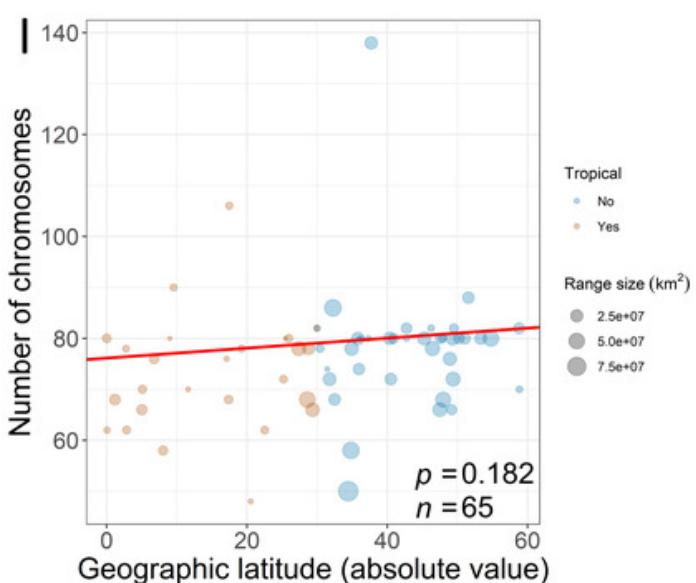


Figure 3

Competing models in the phylogenetic confirmatory path analysis

Competing models for testing the associations of geographic range size (Range) with genome size, chromosome number (Chromosomes), body mass, relative brain mass and latitude in birds

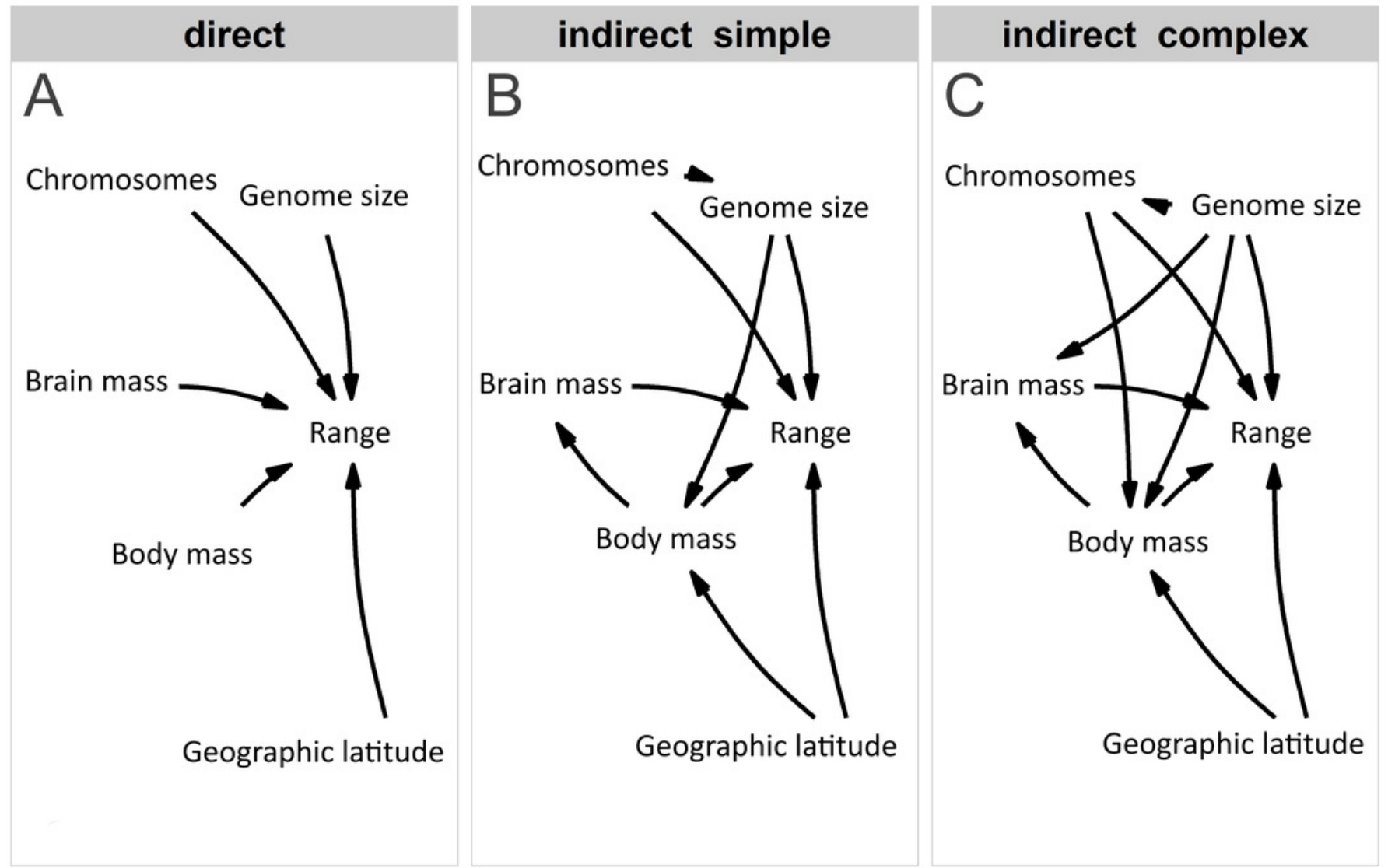

Models 
Figure 4

Associations of geographic range size with $(A)$ genome size $(B)$ body mass of birds, and (C) geographic latitude

Fitted lines (red) are derived from the phylogenetic generalized least squares models. The effect of body mass and latitude on the residual range size (residuals not explained by genome size) is depicted. Futher explanations: see Figure 2 

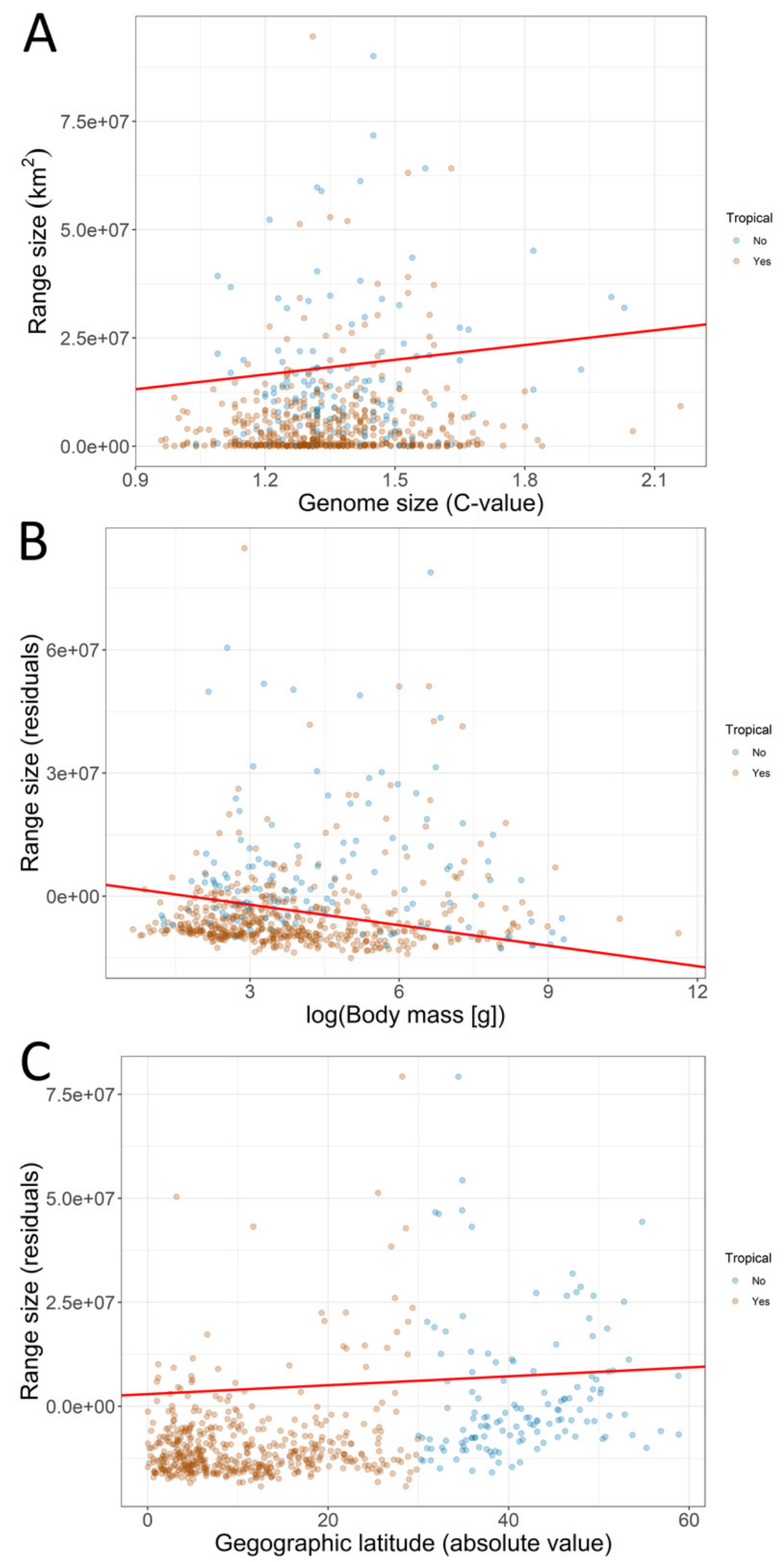
Figure 5

Results from the phylogenetic confirmatory path analysis

Test supporting causal model with standardized path coefficients (A). Standardized coefficients with $95 \%$ confidence intervals (Cls) for explanatory variables associated with geographic range size of birds (B) 


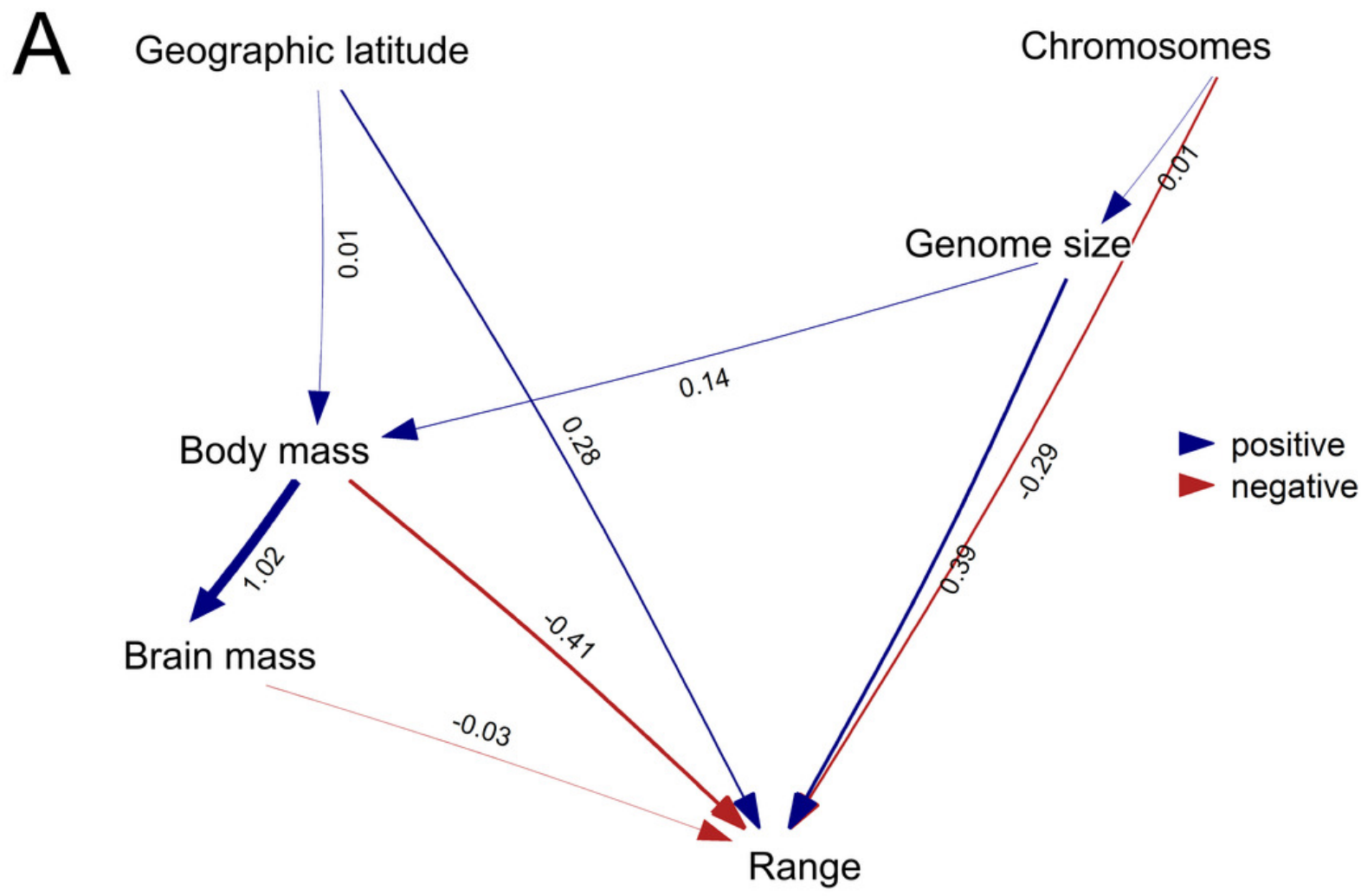

B

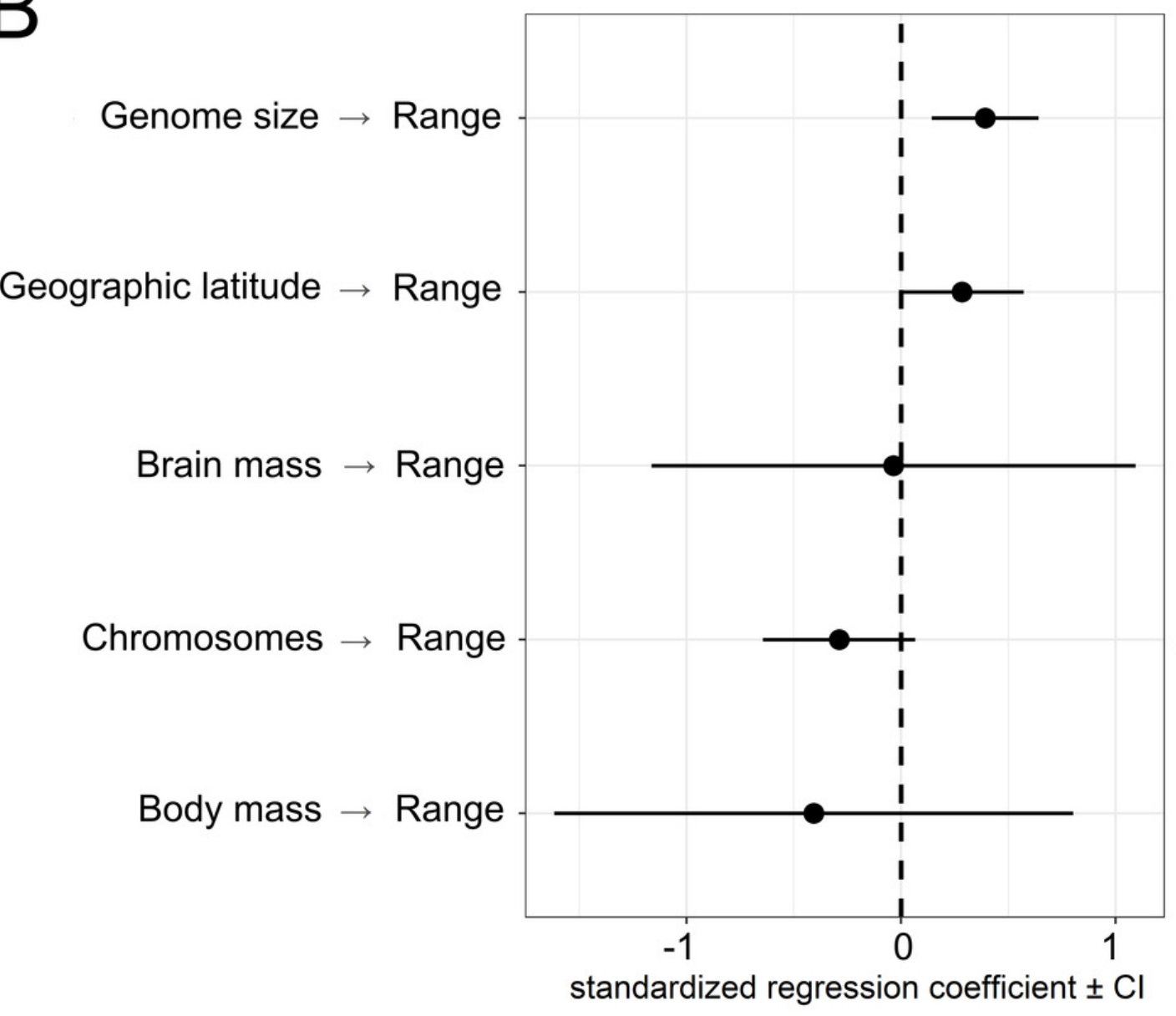




\section{Table $\mathbf{1}$ (on next page)}

Phylogenetic generalized least squares models testing association among geographic species ranges in birds and genome size, chromosome number, body mass, relative brain mass and latitude

Three models differed by available sample size for each explanatory variable. Statistically significant effects have emboldened P-values 
1 Table 1.

\begin{tabular}{|c|c|c|c|c|}
\hline $\begin{array}{l}\text { Model 1st }(\mathrm{N}=637 \\
\text { species })\end{array}$ & & & & \\
\hline Effect & estimate & $S E$ & $t$ & $P$ \\
\hline (Intercept) & 2947223.7 & 13563675.8 & 0.217 & 0.828 \\
\hline Genome size & 11347387.5 & 3810612.2 & 2.978 & 0.003 \\
\hline Body mass & -1666844.5 & 792465.3 & -2.103 & 0.036 \\
\hline Geographic latitude & 107082.4 & 34917.7 & 3.067 & 0.002 \\
\hline \multicolumn{5}{|l|}{ Model 2nd $(\mathrm{N}=311)$} \\
\hline Effect & estimate & $S E$ & $T$ & $P$ \\
\hline (Intercept) & 1282122.5 & 17644249.3 & 0.073 & 0.942 \\
\hline Genome size & 16502711.4 & 5846290.2 & 2.823 & 0.005 \\
\hline Body mass & -2265842.6 & 1127589.4 & -2.009 & 0.045 \\
\hline Brain mass (residual) & -1224487.9 & 5200002.4 & -0.235 & 0.814 \\
\hline Geographic latitude & 27604.6 & 57284.6 & 0.4882 & 0.630 \\
\hline \multicolumn{5}{|l|}{ Model 3rd $(\mathrm{N}=65)$} \\
\hline Effect & estimate & $S E$ & $T$ & $P$ \\
\hline (Intercept) & 25833067.5 & 31459858.8 & 0.821 & 0.415 \\
\hline Genome size & 29848628.7 & 11134362.6 & 2.681 & 0.009 \\
\hline Chromosome number & -345377.8 & 276973.9 & -1.247 & 0.217 \\
\hline Body mass & -3923399.6 & 1685932.1 & -2.327 & 0.023 \\
\hline Brain mass (residual) & 264551.6 & 8961357.9 & 0.030 & 0.976 \\
\hline Geographic latitude & 25833067.5 & 31459858.8 & 0.821 & 0.415 \\
\hline
\end{tabular}

2

3

4 


\section{Table 2 (on next page)}

Results of the phylogenetic confirmatory path analysis

Different sets of models are compared (see Figure 3) Explanations: $k$ - independence claims made by the model, $q$ - the number of parameters, $C$ - the $C$ statistic, $P$ - $p$-value for $C, C I C C$ the $C$-statistic information criterion corrected for small sample sizes, $\triangle C I C C$ - the difference in CICC with the top model, I - the associated relative likelihoods, $w$ - CICC weights (w). A significant $p$ indicates that the available evidence rejects the model 
1 Table 2.

\begin{tabular}{|c|c|c|c|c|c|c|c|c|}
\hline Model & $k$ & $q$ & $C$ & $p$ & $C I C c$ & $\triangle C I C c$ & $l$ & $w$ \\
\hline indirect simple & 6 & 15 & 13.029 & 0.367 & 52.824 & 0.000 & 1.000 & 0.853 \\
\hline indirect complex & 4 & 17 & 9.323 & 0.316 & 56.345 & 3.520 & 0.172 & 0.147 \\
\hline direct & 10 & 11 & 93.275 & 0.000 & 120.256 & 67.431 & 0.000 & 0.000 \\
\hline null & 15 & 6 & 113.251 & 0.000 & 126.700 & 73.875 & 0.000 & 0.000 \\
\hline
\end{tabular}

2

3 